\title{
Developing Story Book in English For Pre Schoolers in Medan
}

\author{
Zelika Rahmi \\ Post Graduate Programme of English Applied Linguistic \\ State University of Medan \\ Email : zelikarahmi@gmail.com
}

\author{
Prof.Amrin Saragih, Ph.D, Prof.Dr Sri Minda Murni M.S \\ Post Graduate Programme of English Applied Linguistic \\ State University of Medan
}

Abstract- The objectives of the study was To find out to what extent does the design of story book in English match the preschoolers' language development, to find out how story book in English designed to cope with the Pre-schoolers, to find out the reason why story book in English designed as it was for preSchoolers. The study was research and development. The existing story book was Moo's Smelly Jumper from David Brown. There were several uncommon words, and the book was not intended in indicators K-13 Curricullum. The researcher wanted to develop a new story book in English for Preschoolers in Medan based on the position of EFL in Indonesia and the preschoolers' language development in English. The story book was about my pets and me. The researcher develop 6 of pets, cat, rabbit, fish, bird, dog, and rooster. The researcher create the uncommon words to be common word to the preschoolers by presenting the explanation of picture of the object, and the function of the object. the story book was intended to the indicator in K-13 Curricullum. The findings of the study showed that (1) The findings of the existing story book the total score in general were " 2 " (the criteria was partially met). And then, preschoolers' language development, namely $80 \%$ matched with Slobin's theory in Semantic, $76 \%$ in Grammatic and $72 \%$ preschoolers in Phonology. (2). Based on the validation of the book by the experts, the book got some the revision in the content and in the layout. Finally the book would be : The content : Included the learning outcome, the text was intended to achieve the indicator of $K-13$ curricullum, namely preschoolers are able to love the pets such as rabbit, cat, dog, birds, and roooster. The layout : the size of page number was not too big, the background was colorfull to attrack The preschoolers' attention. The series book of "Gunggung is my Dog, Brave Rooster, Miaw the Cheerfull cat, Bird's sad whistle, and Missing Fish " had been design to achieved the standard competence which was written in syllabus kemendikbud no 37, "the preschoolers can love the God's living things" where the theme was "Pets" in the first semester. Based on the findings, it can be concluded that the book was appropriate for Preschoolers in Medan. some suggestion were directed to To teacher of Preschool in Medan supposed giving more attention to the preschoolers' language development in Medan in doing story telling by using a story book in English, to other researcher, it was suggested that this reseach could be further expanded, elaborated, and explored in other field in ordet to contribute the development, especially in story book, and to all the readers, it was suggested to use this research as the reference for other research in educational research and Development.

Keywords : develop, story book, PreSchoolers

\section{INTRODUCTION}

\subsection{Background of the Study}

Reading a storybook to young children is regarded as an important activity that supports literacy development (Bus, Van IJzendoorn, \& Pellegrini, 2015). However, although extensive evidence is available on the relationship between book reading and children's oral language, little evidence exists on the positive relationship between this activity and children's early print knowledge.

Robert (2014), Teachers can use storybooks to complement an English language course or as the main teaching resource. Storybooks can act as a springboard for a wide variety of activities to develop children's English language skills. Libby (2015). "It might be in the images, it might be in the text ... it's always on the side of the child, so it's not a moralising tone from the author." Great stories also use language that is rich and challenging, she adds. In children's book there will be words that a kid doesn't know. That doesn't matter because that's how you actually learn more complex language by reading books that contain it so you are exposed to it in context."

As my own experience, actually some new words which was found in the story book, I have known the words when I was doing my bacheloor degree in english departement. But the book was intendeed for pre schooler. Based on the reasons, it was differant from Libby's theory before. The researcher hyphothese that vocabullary in English for Indonesian PreSchooler is different from Pre-Scooler in other places. That's why the researcher wanted to create a series of story book in English for Pre-Schoolers.

\subsection{The Objective of the Research}

To find out to what extent does the design of story book in English match the preschoolers' language development, to find out how story book in

\section{LITERATURE REVIEW}

\section{Language Acquisition}

Southerland (1989 :201) stated language acquisition acquisition is the process of learning a first language in children. The term "acquisition" is prefered to 'learning' tends to be used by psychologists in a narrowly technical sense which is capable of accounting for the process whereby children who come to achieve a fluent control of their native language in a relatively short time. 


\section{Child's language development}

Child's ability to understand language develops faster than the ability to speak it. Receptive language is the ability to understand language, and expressive language is the ability to use language to communicate. If her mother tells her fifteenmouthe-old child to put the toy back in the toy chest, he may follow her instructions eventhough he can't repeat them himself (Menyuk : 1971).

\section{English Learning teaching in Preschool}

English for early childhood so that learning can achieve the goal as expected:

(1). Complete learning activities with visual media, realia and movements and a combination of spoken language with 'body language' or 'demonstration'.

(2). Involving children in the manufacture of visual media or realia.

(3). Move from one activity to another quickly

(4). Build a routine in the classroom using English

(5). Use the mother tongue if necessary

6). Teach by theme and stimulate the imagination and creativity of children.

(7). Using stories and contexts that children already know

(8). Invite surrounding communities (parents, students, etc.) who can speak English to engage in class

(9). Collaborate with other teachers at your school

(10). Communicate with teachers or teachers for other early childhood outside your school (Shin, 2006)

Emglish designed to cope with the Pre-schoolers, and to find out the reason why story book in English designed as it was for pre-Schoolers

The research questions were :

a. To what extent did the design of story book in English match the preschoolers' language development?

b. How was the story book in English designed to cope with the Pre-schoolers?

c. Why was the story book in English designed as it is for PreSchoolers?

\section{Course Design}

Course design is the process by which the raw data about a learning need is interpreted in order to produce an integrated

This research will be conducted by applying research and development (R\&D) design.

1.Research Instrument

The instrument is observation, questioner, and interview

2. Description of the participant

The participants are five teachers in one of private school on Medan. they are pre school teachers.

3. Reseach Procedure

This research is classified into an Educational Research and Development (R\&D). series of teaching-learning experiences, whose ultimate aim is to lead the learnes to a particular state of knowledge.

\section{Learning Materials}

According to Depdiknas (2004) learning materials is a generic term for resources, which can be stand alone, integrated or complementary to units/ modules, and which engage students in learning processes.

In order to provide valuable experience to the students, story telling should be linked to the real environment that was around the students

\section{Learning Materials for Preschoolers}

Story book is one of learning material which is used in Preschool. Preschoolers are four years old where they are as continuity of playgroup. Teacher of preschool will do story telling and choose one story book. As Mulich (2010) said that a good story book can be as the foundation of learning in the classroom.

\section{Developing story book in English for Preschoolers}

From ages 3-4, most preschoolers become able to:

- Enjoy listening to and talking about storybooks

- Understand that print carries a message.

- Make attempts to read and write.

- Identify familiar signs and labels.

- Participate in rhyming games.

- Identify some letters and make some letter-sound matches.

- Use known letters (or their best attempt to write the letters) to represent written language especially for meaningful words like their names or phrases such as "I love you.

\section{Relevant Studies}

Previous investigations have looked into individual aspects of story reading. Morrow (2015) focused on including library comers in classrooms to increase independent reading, using story retelling to improve comprehension, and interactive behaviors that that encourage children's active involvement in story reading events with children from both middle-class and lower SES backgrounds.

\section{METHODOLOGY}

This research will be conducted by applying research and development (R\&D) design.

\section{DATA ANALYSIS}

\section{Evaluation of existing reading maerials}

The rubric was about foundational reading skills (print concepts, phonological awareness, phonemic awareness, phonics, and fluency); reading comprehension for literary and informational texts; writing development and skills; speaking and listening development and skills; and language 
development and skills (academic language skills and vocabulary).

\section{Preschoolers' language development}

Bades on the observation and based on Slobin's theory, the result was

It could be conluded that it was almost match with the slobin theory about In 2-5 years old, the child understand and express relational contrasts, response in action and response by telling were $81 \%$. All of the students got correct answer in opposite. Meanwhile in giving response in action and in telling, there were two preschoolers getting uncorrect answer.

Based on the overall rating in Grammatic of singular and plural noun, Pronoun, and auxiliary verb were $76 \%$. The preschoolers were excellent in singular or plural noun. While in pronoun there were two students were getting uncorrect answer and also in auxiliary verb, there were three students were getting uncorrect answer.

Based on the preschoolers' pronounciation above, it could match with slobin theory, In 3-5 years old, a child's pronounciations adequately improve. He or she has already pronounce the words better and nearly correct moreover in easy syllable.

\section{Developing story book in English for Preschoolers}

The strength of Moo Smelly Jumper book such as :

1. The text provided good grammatical structure (language development and skills)

2. There was the repetition of words to create retention. (speaking and listening development)

Thus, the researcher would design the new story book in English for Preschoolers in medan by using the strength and avoid the weaknesses. The book would be design :

1. Using common words (language development and skills)

2. The materials include writing practice by spelling and reading the words first. (writing development and skills)

3. The background of the design would be colorful to attract Preschoolers' attention (Foundational reading skills)

4. Good grammatical structure would be used (language development and skills)

5. The text achieved the standard competence in $\mathrm{k} 13$ curriculum in animal theme, "to love all human beings " (foundational reading skills)

6. There were repetition of words to create retention (speaking and listening development skills)

7. The characters were the human, where it could be as a role play for preschoolers to imagine in their daily life.

\section{VALIDATION}

The story book had been validated by two experts, those were the result of the content and the layout of the story book

\begin{tabular}{|l|l|l|}
\hline No & The content & The layout \\
\hline 1 & $\begin{array}{l}\text { Included the learning } \\
\text { outcome }\end{array}$ & $\begin{array}{l}\text { The size of page number } \\
\text { was not too big }\end{array}$ \\
\hline 2 & $\begin{array}{l}\text { The text was intended to } \\
\text { achieve the indicator of } \\
\text { K-13 curricullum, } \\
\text { namely preschoolers are } \\
\text { able to love the pets such } \\
\text { as rabbit, cat, dog, birds, } \\
\text { and roooster. }\end{array}$ & $\begin{array}{l}\text { The background was } \\
\text { preschoolers attention }\end{array}$ \\
\hline
\end{tabular}

\section{RESULT}

The result of this research could answer the three research problems, they were :

1. The extent design of story book in English such as

(a) The total score for organizational features of Foundational Reading skills were the criteria was partially met.

(b) The total score for organizational features of reading comprehension for literary and informational texts were the criteria was partially met.

(c) The total score for organizational features of writing development skills were the criteria was partially met.

(d) The total score of organizational features in speaking and listening development skills was the criteria was not met

(e) The total score for organizational features of language development skills were, the criteria was partially met.

(f) The total score in general of the existing story book namely the criteria was partially met.

Thus, the total score in general were 2 (the criteria was partially met). And then, preschoolers' language development, namely $80 \%$ matched with Slobin's theory in Semantic, $76 \%$ in Grammatic and $72 \%$ preschoolers in Phonology.

2. The design of story book in English to cope the Preschoolers namely the researcher used the strength of the existing book and change the weakness as the strength of the new book. The design were

a. There would be common words in the story book (language development and skills)

b. The materials include writing practice by spelling and reading the words first. (writing development and skills)

c. The background of the story book would match to the text of the story book (Foundational reading skills)

d. Good grammatical structure would be used (language development and skills)

e. The text was intended for indicator in K-13 curricullum

The result of the validation of the book about the content and the layout, namely the content should be the text had learning outcome for the preschoolers, the text was intended to indicators in K-13, Preschoolers are able to love the pets such as rabbit, cat, dog, bird, and rooster.

The layout should be the size of page number was not too big the background was colorfull to attrack the Preschoolers' attention. 
3. The reason for developing story book namely to fulfill the weakness of the existing book entitled "Moo's Smelly jumper" and to achieve the indicators of Basic Competence in Curriculum K-13 where :

- Preschoolers loved the pets

- Preschoolers know the name, shape, characters, food and other things of Pets

\section{DISCUSSION}

The overall rating subsection was where a reviewer records an overall holistic rating after considering the entire set of instructional materials. For example, if a 3 is recorded across all the items, a 3 would be expected in the overall rating section. Alternatively, patterns of strengths and weaknesses at the item level for component skills within content areas can be noted (for example, one set of instructional materials may be strong in foundational skills and weak in reading comprehension skills, whereas the opposite may be true in another set).

\section{CONCLUSION}

1. The findings of the existing story book the total score in general were "2" (the criteria was partially met). And then, preschoolers' language development, namely $80 \%$ matched with Slobin's theory in Semantic, $76 \%$ in Grammatic and $72 \%$ preschoolers in Phonology.

2. Based on the validation of the book by the experts, the book got some the revision in the content and in the layout. Finally the book would be :

The content

(a) Included the learning outcome

(b) The text was intended to achieve the indicator of K-13 curricullum, namely preschoolers are able to love the pets such as rabbit, cat, dog, birds, and roooster.

The layout

(a) The size of page number was not too big

(b) The background was colorfull to attrack The preschoolers' attention

3. The series book of "Gunggung is my Dog, Brave Rooster, Miaw the Cheerfull cat, Bird's sad whistle, and Missing Fish " had been design to achieved the standard competence which was written in syllabus kemendikbud no 37, "the preschoolers can love the God's living things" where the theme was "Pets" in the first semester.

\section{REFERENCES}

[1] Foorman, B.R. (2016). Rubric For Evaluating reading/language arts instructiona materials for Kindergarten to grade 5. Florida : Florida State University

[2] Gall, M.D,J.P.,\& Borg, W.R.(2003). Education Research : An Introduction (7th Ed). USA : Pearson Education

[3] Gleeson, L.(2015).Story Book For Teenagers and Children. Australia : University of Sidney

[4] Pallegrini (2015), Story Book for Kids. Australia : University of Sidney

[5] Roberts, J., Jurgens, J. \& Burchinal, M. (2014). The Role of Home Literacy Practices in Preschool Children's Language and Emergent Literacy Skills. Journal of Speech, Language, and Hearing Research. 48(2), 345-359.
[6] Slobin, D.I. (1994). The Human Language Series 2. Colombia : Colombia University

[7] Slobin, D.I (1997). The Crosslinguistic Study of Language Acquisition. New York : University of California et berkeley

[8] Wright, A. (2004). Creating Stories With Children. New York : Oxford University Press. 